УДК 618.14-006.36-089.168.1.-06:616.89-008.19

DOI 10.11603/24116-4944.2016.2.6859

\author{
${ }^{\odot A . ~ В . ~ Б о и ̆ ч у к ~}{ }^{1}$, Т. В. Формазюк ${ }^{1}$, Н. Д. Коблош ${ }^{2}$ \\ ${ }^{1}$ ДВНЗ «Тернопільсъкий державний медичний університет \\ ілені І. Я. Горбачевсъкого МОЗ України» \\ ${ }^{2}$ ДУ «Інститут педіатрї̈, акушерства і зінеколозї \\ Національної академї медичних наук України»

\section{ОЦІНКА ЯКОСТІ ЖИТТЯ У ЖІНОК ІЗ ФІБРОМІОМОЮ МАТКИ ДО ТА ПІСЛЯ ОПЕРАТИВНОГО ЛІКУВАННЯ}

ОЦІНКА ЯКОСТІ ЖИТТЯ У ЖІНОК ІЗ ФІБРОМІОМОЮ МАТКИ ДО ТА ПІСЛЯ ОПЕРАТИВНОГО ЛІКУВАННЯ. ДосВіД ПОКаЗУє, що у жінок з міомою матки підвищений рівень тривожності, а це може призвести до зниження активності і якості життя, а в подальшому до соціальної та особистої ізоляції в період оперативного лікування. У зв'язку з цим оцінка якості життя пацієнток в наш час набуває все більшого значення поряд з основними традиційними методиками оцінки ефективності лікування та наслідків захворюваності. За отриманими результатами, якість життя у жінок репродуктивного та пострепродуктивного віку, які перенесли оперативне лікування з приводу міоми матки, на основі запропонованої нами терапії покращилася.

ОЦЕНКА КАЧЕСТВА ЖИЗНИ У ЖЕНЩИН С ФИБРОМИОМОЙ МАТКИ ДО И ПОСЛЕ ОПЕРАТИВНОГО ЛЕЧЕНИЯ. ПРАКтика показывает, что у женщин с миомой матки повышен уровень тревожности, а это может привести к снижению активности и качества жизни, а в дальнейшем к социальной и личной изоляции в период оперативного лечения. В связи с этим оценка качества жизни пациенток в наше время приобретает все большее значение наряду с основными традиционными методиками оценки эфффективности лечения и последствий заболеваемости. По полученным результатам, качество жизни у женщин репродуктивного и пострепродуктивного возраста, перенесших оперативное лечение по поводу миомы матки, на основе предложенной нами терапии улучшилось.

EVALUATION OF QUALITY OF LIFE OF WOMEN WHO SUFFER FROM UTERINE FIBROIDS BEFORE AND AFTER SURGERY. Experience shows that women suffering from uterine fibroids have an increased level of anxiety. It can lead to social and personal isolation during surgery. Thereby, nowadays the assessment of patients ' quality of life becoming increasingly important alongside the main traditional methods of evaluating the effectiveness of treatment and the effects of disease. According to the results, quality of life of women of reproductive and post reproductive age whohave undergone a surgical treatment for uterine fibroids, based on our therapy, improved.

Ключові слова: фріброміома матки, оперативне лікування, якість життя.

Ключевые слова: фрибромиома матки, оперативное лечение, качество жизни.

Key words: uterine fibroids, surgical treatment, quality of life.

Вступ. Невпинно зростаючий темп сучасного техногенного суспільства, негативні зміни екології, режиму харчування, праці і відпочинку викликають зміни механізмів адаптації і зумовлюють зростання захворювань репродуктивної системи жінки [5]. У зв'язку з цим проблема доброякісних пухлин матки викликає неабиякий інтерес вчених вже не перший рік $[1,7,10]$.

Проблема лікування хворих на міому матки продовжує залишатися актуальною в сучасній гінекології через високу частоту цієї патології, а також її негативний вплив на репродуктивну систему і загальний стан здоров'я жінки $[3,4,11]$. В останнє десятиліття намітилася тенденція до збільшення частоти виникнення даного патологічного стану у молодих жінок. Лейоміома матки $є$ пухлиною жіночої репродуктивної системи, що найбільш часто зустрічається і від якої у світі страждає кожна 4-5-та жінка пізнього репродуктивного та перименопаузального віку $[1,14,17]$. За даними різних авторів, близько $30 \%$ жінок піддаються хірургічним втручанням на статевих органах $[8,11]$, причому перше місце займають операції з приводу лейоміоми матки $[2,16]$.

Міома матки - для багатьох жінок цей діагноз звучить, як грім серед ясного неба, і часто буває так, що невірне уявлення про цей діагноз прирікає пацієнтку на важкі переживання, що погіршує якість життя жінки $[6,9,12]$.
У зв'язку з цим оцінка якості життя пацієнток в наш час набуває все більшого значення поряд із основними традиційними методиками оцінки ефективності лікування та наслідків захворюваності, такими, як визначення тривалості життя та рівня смертності $[13,15]$.

Метою роботи була оцінка якості життя у жінок репродуктивного та пострепродуктивного віку, які перенесли оперативне лікування з приводу міоми матки, на основі запропонованої нами терапії.

МАТЕРІАЛИ ТА МЕТОДИ. НамИ бУЛо комплексно обстежено 120 пацієнток 3 міомою матки у віці від 37 і до 54 років, які були розподілені на 2 групи залежно від використаної терапії: загальноприйняті реабілітаційні заходи (I група-контрольна) і запропонована нами терапія (II група - дослідна). Кожну групу розподілено на підгрупи (по 15 жінок у кожній) залежно від об'єму виконаного оперативного втручання: Аекстирпація матки з придатками, Б - екстирпація матки без придатків, В - міомектомія, Г-емболізація маткових артерій.

Обстеження пацієнток з міомою матки розпочиналось на доопераційному етапі та продовжувалось у післяопераційному періоді.

Запропонована нами терапія полягала у тому, що кваттрекс призначався по 250 мг 2 рази на добу за 1-2 дні до оперативного лікування та 5-7 днів у післяопераційному періоді. 
Кваттрекс $є$ похідним у-аміномасляної кислоти та фенілетиламіну. Фармакотерапевтична група: психостимулятори та ноотропні засоби (Код АTC N06B X).

Показання до застосування: астенічні і тривожно-невротичні стани, тривожність, страх, невроз нав'язливих станів, психопатія, безсоння, нічний неспокій, а також профрілактика стресових станів, перед операціями чи болючими діагностичними дослідженнями.

РЕЗУЛЬТАТИ ДОСЛІДЖЕННЯ ТА ЇХ ОБГОВОРЕННЯ. На основі стандартизованого аналізу виявлено обмежене застосування методів визначення якості житті, пов'язаної зі здоров'ям. Докази свідчать про те, що вплив міоми матки на якість життя можливо виміряти. Для цього застосовується, головним чином, спеціально розроблений опитувальник у вигляді анкети «Симптоми фріброміоми матки і якість життя» (Uterine Fibroid Symptom and Quality of Life (UFS-QOL)).

Всі пацієнтки з фріброміомою матки відмічали порушення якості життя (у I і II групах) (спостерігалася пряма взаємозалежність по шкалах Concern, Activities, Energy/ mood, Control, Self-conscious, Sexual function) залежно від об'єму оперативного втручання, станом до чи після оперативного втручання. Результати досліджень до оперативного лікування представлені в таблиці 1.

Мультиваріантний аналіз шкали UFS-QOL показав, що більше покращення симптомів і балів в I і II групах спостерігався в післяопераційному періоді порівняно 3 доопераційним. Результати досліджень після оперативного лікування представлені в таблиці 2.

Також виявлена закономірність показників «якості життя» у жінок 3 міомою матки: | $A>\mid$ Б > | В >| Г та II A >II Б >II B >II Г. Ми робимо висновок, що емболізація маткових артерій найпозитивніше впливає на якість життя жінок, порівняно з такими об'ємними втручаннями, як екстирпація матки з придатками та без придатків.

Результати опитування корелюють 3 висновками якісних досліджень, переживаннями та страхами жінок 3 приводу проведення гістеректомії, а також з психологічним впливом, який вона спричиняє. Тому дуже важливо, щоб будь-яке визначення якості життя жінок відображало врахування суб'єктивного відчуття жінок. Для точності визначення результатів по груповому порівнянні отримали співвідношення суми всіх шкал якості життя жінки HRQL TOTAL= I:II= 67,08:33,18. За отриманими результатами можна стверджувати, що якість життя жінок на фоні запропонованої терапії у 2 рази вища порівняно із загальноприйнятими методами лікування.

ВИСнОВкИ. Підбиваючи підсумки проведеної роботи, можна стверджувати, що якість життя жінок на фоні запропонованої терапії у 2 рази (HRQL TOTAL= I:II= 67,08: $33,18)$ вища на основі оцінки якості життя пацієнток за ан-

Таблиця 1. Диференційні показники симптомів у жінок з фіброміомою матки до оперативного лікування

\begin{tabular}{|c|c|c|c|c|c|c|c|c|}
\hline \multirow{3}{*}{ Симптоми } & \multicolumn{8}{|c|}{ До оперативного лікування } \\
\hline & \multicolumn{4}{|c|}{ загальноприйняті реабілітаційні заходи } & \multicolumn{4}{|c|}{ запропонована терапія } \\
\hline & IA & 15 & I B & IГ & II A & II Б & II B & II \\
\hline $\begin{array}{l}\text { Увага } \\
\text { (Concern) }\end{array}$ & $90,12 \pm 0,18$ & $80,1 \pm 0,12$ & $60,2 \pm 0,17$ & $40,17 \pm 0,18$ & $44,3 \pm 0,14$ & $40,2 \pm 0,15$ & $30,1 \pm 0,20$ & $20,01 \pm 0,13$ \\
\hline $\begin{array}{l}\text { Aктивність } \\
\text { (Activities) }\end{array}$ & $92,86 \pm 0,12$ & $84,2 \pm 0,17$ & $61,4 \pm 0,30$ & $43,18 \pm 0,13$ & $43,12 \pm 0,13$ & $42,01 \pm 0,17$ & $30,3 \pm 0,18$ & $24,71 \pm 0,42$ \\
\hline $\begin{array}{l}\text { Енергія } \\
\text { (Energy/mood) }\end{array}$ & $92,86 \pm 0,04$ & $70,2 \pm 0,18$ & $54,6 \pm 0,31$ & $38,18 \pm 0,14$ & $42,4 \pm 0,14$ & $42,3 \pm 0,14$ & $30,4 \pm 0,14$ & $17,14 \pm 0,23$ \\
\hline $\begin{array}{l}\text { Настрій } \\
\text { (Control) }\end{array}$ & $90,15 \pm 0,19$ & $83,14 \pm 0,12$ & $61,0 \pm 0,20$ & $40,4 \pm 0,20$ & $44,3 \pm 0,15$ & $42,3 \pm 0,15$ & $30,2 \pm 0,14$ & $20,02 \pm 0,11$ \\
\hline $\begin{array}{l}\text { Самовпевненість } \\
\text { (Self-conscious) }\end{array}$ & $91,67 \pm 0,34$ & $84,3 \pm 0,14$ & $63,4 \pm 0,30$ & $54,2 \pm 0,20$ & $42,47 \pm 0,15$ & $40,3 \pm 0,17$ & $40,3 \pm 0,28$ & $18,33 \pm 0,42$ \\
\hline $\begin{array}{l}\text { Сексуальна фрункція } \\
\text { (Sexual function) }\end{array}$ & $87,15 \pm 0,12$ & $87,2 \pm 0,14$ & $54,2 \pm 0,13$ & $36,4 \pm 0,17$ & $46,2 \pm 0,16$ & $43,0 \pm 0,18$ & $25,27 \pm 0,14$ & $22,5 \pm 0,32$ \\
\hline
\end{tabular}

Таблиця 2. Диференційні показники симптомів у жінок з фіброміомою матки після оперативного лікування

\begin{tabular}{|c|c|c|c|c|c|c|c|c|}
\hline \multirow{3}{*}{ Симптоми } & \multicolumn{8}{|c|}{ Після оперативного лікування } \\
\hline & \multicolumn{4}{|c|}{ загальноприйняті реабілітаційні заходи } & \multicolumn{4}{|c|}{ запропонована терапія } \\
\hline & IA & 15 & $\mathrm{IB}$ & $\mathrm{II}$ & II A & II 5 & II B & II Г \\
\hline $\begin{array}{l}\text { Увага } \\
\text { (Concern) }\end{array}$ & $84,12 \pm 0,28$ & $78,1 \pm 0,17$ & $58,2 \pm 0,14$ & $39,18 \pm 0,17$ & $42,3 \pm 0,14$ & $38,3 \pm 0,25$ & $28,1 \pm 0,10$ & $19,01 \pm 0,21$ \\
\hline $\begin{array}{l}\text { Активність } \\
\text { (Activities) }\end{array}$ & $89,26 \pm 0,14$ & $81,2 \pm 0,16$ & $59,4 \pm 0,21$ & $41,28 \pm 0,23$ & $41,22 \pm 0,13$ & $40,01 \pm 0,27$ & $28,2 \pm 0,16$ & $22,51 \pm 0,12$ \\
\hline $\begin{array}{l}\text { Eнергія } \\
\text { (Energy/mood) }\end{array}$ & $90,36 \pm 0,14$ & $68,2 \pm 0,28$ & $52,3 \pm 0,21$ & $36,18 \pm 0,23$ & $39,2 \pm 0,14$ & $39,3 \pm 0,24$ & $28,3 \pm 0,18$ & $16,14 \pm 0,3$ \\
\hline $\begin{array}{l}\text { Hacтрій } \\
\text { (Control) }\end{array}$ & $87,15 \pm 0,29$ & $81,13 \pm 0,13$ & $57,0 \pm 0,30$ & $39,6 \pm 0,30$ & $42,14 \pm 0,25$ & $39,3 \pm 0,16$ & $29,2 \pm 0,4$ & $19,12 \pm 0,21$ \\
\hline $\begin{array}{l}\text { Самовпевненість } \\
\text { (Self-conscious) }\end{array}$ & $89,67 \pm 0,24$ & $83,3 \pm 0,14$ & $61,4 \pm 0,23$ & $52,2 \pm 0,18$ & $38,17 \pm 0,35$ & $38,2 \pm 0,17$ & $37,3 \pm 0,18$ & $17,23 \pm 0,22$ \\
\hline $\begin{array}{l}\text { Сексуальна фрункція } \\
\text { (Sexual function) }\end{array}$ & $85,15 \pm 0,13$ & $85,2 \pm 0,12$ & $53,2 \pm 0,13$ & $33,4 \pm 0,16$ & $45,2 \pm 0,26$ & $41,12 \pm 0,18$ & $23,17 \pm 0,15$ & $20,5 \pm 0,22$ \\
\hline
\end{tabular}


кетою-опитувальником «Симптоми фрібром матки і якість життя». Запропонована нами терапія (кваттрекс по 250 мг 2 рази на добу за 1-2 дні до оперативного лікування, та у післяопераційному періоді кваттрекс по 250 мг 2 рази на добу 5-7 днів) є ефективною для корекції психоемоційних станів у жінок з міомою матки.

ПЕРСПЕКТИВИ ПОДАЛЬШИХ ДОСЛІДЖЕНЬ. ПИтання про вивчення якості життя пацієнток залишається актуальним. Лише поодинокі публікації $[14,18]$ відо- бражають проблему, що стосується оцінки якості життя пацієнток, що перенесли гістеректомію.

Подальшого вивчення потребує вплив гістеректомії при доброякісних пухлинах матки на подальше здоров'я жінки, а також поглиблене вивчення особливостей перебігу захворювання та стану гормонального гомеостазу. Перспективним $€$ визначення дезадаптивних якостей особистості, оцінки параметрів психологічного профрілю (частоти і ступеня тяжкості психологічних порушень).

\section{СПИСОК ЛІТЕРАТУРИ}

1. Brown M. A. MR imaging of benign uterine disease. Magn. Reson.Imaging Clin. 2006:4:439-453.

2. Fagotti A. Postoperative pain after conventional laparoscopy and laparoendoscopic single site surgery (LESS) for benign adnexal disease: a randomized trial / A. Fagotti // Fertil Steril. - 2011. - Vol. 1. - P. 255-259.

3. Hovsepian D. A prospective comparison of the impact of uterine artery embolization, myomectomy, and hysterectomy on ovarian function / D. Hovsepian // J. Vasc. Interv. Radiol. 2006. - Vol. 7. - P. 1111-1115.

4. Mara M. Uterine fibroid embolization versus myomectomy in women wishing to preserve fertility: preliminary results of a randomized controlled trial / M. Mara // Eur. J. Obstet. Gynecol. Reprod. Biol. - 2006. - Vol. 2. - P. 226-233.

5. Spies J. B. The FIBROID Registry: symptom and qualityof-life status 1 year after therapy / J. B. Spies // Obstet. Gynecol. - 2005. - Vol. 6. - P. 1309-1318.

6. Voogt M. J. Sexual functioning and psychological wellbeing after uterine artery embolization in women with symptomatic uterine fibroids / M. J. Voogt // Fertil. Steril. - 2009. Vol. 2. - P. 756-761.

7. Буянова С. Н. Современные представления об этиологии, патогенезе и морфогенезе миомы матки / С. Н. Буянова, М.В.Мгелиашвили, С. А. Петракова // Российский вестник акушера-гинеколога. - 2008. - № 6. - С. 45-51.

8. Давыдов А. И. Диффференцированный подход к выбору метода органосберегающего лечения больных миомой матки / А. И. Давыдов, А. Н. Стрижаков, В. М. Пашков // Мать и дитя : тезисы докладов VII Российского форума. - 2005 - С. 366-367.
9. Доброхотова Ю. Э. Постгистерэктомический синдром / Ю. Э. Доброхотова // Вопросы гинекологии, акушерства и перинатологии. - 2010. - № 6. - С. 90-94.

10. Кулаков В. И. Гинекология. Национальное руководство / В. И. Кулаков, Г. М. Савельева, И. Б. Манухин. ГЭОТАР-Медиа, 2009. - С. 1076-1088.

11. Ланчинский В. И. Современные аспекты патогенеза, диагностики и хирургического лечения миомы матки : авторефр. дисс. д-ра мед. наук : 14.00.01 / Ланчинский Виктор Иванович. - 2008. - С. 1-48.

12. Оценка индекса тяжести состояния и качества жизни больных до и после ЭМА при миоме матки / [Д. Ж. Максутова и др.] // Современные методы диагностики и лечения гинекологических заболеваний. - М., 2009. - С. 247-248.

13. Райгородский Д. Я. Практическая психодиагностика Методики и тесты / Д. Я. Райгородский. - Издательство Бахpax, 2006. - С. 652-678.

14. Рудь В. А. Влияние гистерэктомии в репродуктивном возрасте на изменения сексуальной функции и развитие урогенитальных расстройств / В. А. Рудь // Репродуктивное здоровье женщины. - 2007. - № 4. - С. 148-150.

15. Селье Г. Стресс без дистресса / Г. Селье. - Прогресс, 1982. - С. $124-127$.

16. Стрижаков А. Н. Доброкачественые заболевания матки / А. Н. Стрижаков. - ГЭОТАР-Медиа, 2011. - С. 286-288.

17. Стрижаков А. Н. Миома матки: патогенез, диагностика, лечение / А. Н. Стрижаков // Вопросы гинекологии, акушерства и перинатологии. - 2008. - № 4. - С. 7-18.

18. Кулаков В. И. Оперативная гинекология / В. И. Кулаков, Н. Д. Селезнева, В. И. Краснопольский. -1999. - С. 167-235. 